\title{
Gazette
}

\section{APSA Awards Presented at the 1989 Annual Meeting}

\author{
DISSERTATION AWARDS \\ (Each award includes a cash prize of $\$ 250$ )
}

Gabriel A. Almond Award, for the best doctoral dissertation completed and accepted during 1987 or 1988 in the field of comparative politics.

Award Committee: Roberta Sigel, Rutgers University, chair; Peter Lange, Duke University; and David Pion-Berlin, Ohio State University.

Recipient: Jeffrey Herbst, Princeton University.

Dissertation: "Policy Formulation and Implementation in Zimbabwe: Understanding State Autonomy and the Focus of Decision-Making," submitted by Yale University.

Dissertation Chair: William Foltz.

Recipient: Sven Steinmo, University of Colorado.

Dissertation: "Taxes, Institutions and the Mobilization of Bias: The Political Economy of Taxation in Britain, Sweden and the United States," submitted by the University of California, Berkeley.

\section{Dissertation Chair: Aaron Wildavsky.}

Citations: Jeffrey Herbst's dissertation on state autonomy in Zimbabwe is a stimulating and compelling study of decision-making in an African nation that has recently undergone radical political change. Herbst's rich and complex blend of empirical investigation and theorizing about the allocation of resources by governmental agencies has deepened our understanding of state actions and state autonomy. His analysis departs from previous theorizing about African states which tended to be excessively generalized and empirically unfounded. Herbst's point of departure is to employ mid-level generalizations about state autonomy and decision-making in a way that persuasively anchors the theoretical discussion of the state with the concrete realities of political life. In this manner, he is able to generate falsifiable predictions about state behavior.

Rather than treat the state as a monolithic entity, he conceives of the state as a collection of distinct and interrelated institutions whose capacities for autonomous action vary. The determinants of state autoniomy are both structural and situational. A given institutional arrangement may exhibit varying degrees of state autonomy, depending upon the strategic and tactical choices made by pressure groups at one end and policy makers at the other. Thus, the interaction between state agencies and interest groups across an array of issue domains, along with the built-in legal and organizational features of the state institutions combine to explain the interesting and at times unexpected patterns of resource allocation that emerge in Zimbabwe. His generalizations about the determinants of state autonomy extend the relevance of the findings beyond the territorial boundaries of Zimbabwe, and make Herbst's contribution to the theoretical and empirical study of states a significant one.

Sven Holger Steinmo's Taxes, Institutions and the Mobilizotion of Bios: The Politics/ Economy of Taxation in Britain. Sweden and the United States is an ambitious, well-crafted and truly comparative study explaining substantial differences in the tax systems of three advanced industrial democracies. It is distinguished by the detail and clarity of its empirical analysis of the complex tax systems of Sweden, Britain and the United States, by the challenge which this comparative analysis represents to the conventional wisdom about how these countries can be expected to distribute tax burdens across different social strata, and by the coherence and parsimony of the explanation offered for the diversity in tax structures. It has the additional virtue of making a substantial contribution to the resurgent interest in the comparative study of the relationship between political institutions and public policy outputs and outcomes.

Steinmo explores in detail the tax systems of the three countries, using a combination of national sources and interviews to identify the chief features of each. He argues that it is the tax system, that is, the configuration of all taxes 
employed to raise revenues, rather than individual types of taxes which must be examined if the impact of taxes on individuals and on national economic performance is to be understood. Despite the complexity which this approach necessarily entails he is able to distill three central features of each tax system: the overall level of tax "yield," the incidence of tax burdens on diverse social strata identified by their income levels, and the likely impact of the tax system on investment and capital formation. From this analysis, he discovers that the three national tax systems differ substantially, and in ways which are often unexpected.

Steinmo's dissertation is an excellent example of the application of broad-scale institutional analysis to the explanation of cross-national differences in public policy. He has brought together and effectively synthesized detailed policy information on three cases, thereby identifying three distinctive outcomes which defy conventional explanations. He has then provided a coherent, parsimonious institutionalist explanation for these outcomes by showing the ways basic characteristics of the political institutions of each of the three national systems influence the preferences and strategies of the relevant actors as well as their access to public policy decision making. In doing so his dissertation makes a superb contribution to comparative analysis of the advanced industrial democracies as well as the broader effort to understand the relationship between political institutions, political power and public policy.

William Anderson Award, for the best doctoral dissertation completed and accepted during 1987 or 1988 in the field of intergovernmental relations.

Award Committee: Paul Peterson, Harvard University, chair; Bruce E. Cain, California Institute of Technology; Janet Clark, University of Wyoming

Recipient: John C. Drew, Williams College.

Dissertation: "Child Labor and Child Welfare: The Origins and Uneven Development of the American Welfare State," submitted by Cornell University.

\section{Dissertation Chair: Ronald King.}

Citation: Professor Drew's dissertation studies the political factors that led to the adoption of mothers' pensions laws in most states by the 1930s. Drawing upon ideas developed by Hugh Heclo, he sees policy innovation as the product of networks of experts who react to the problems created by prior policy changes.

In applying this framework, Professor Drew makes an excellent case for his argument that welfare legislation developed in response to problems arising from the enactment of child labor legislation. Once families that had lost a wage-earner were prohibited from asking their children to help supplement the family income, it became increasingly apparent that widows needed state aid in order to keep the family intact.

Drew not only describes the national connections between the child labor and mothers' pensions movements, but he also shows the way in which the relationship between the two varied from one part of the country to another. It was in the midwest and west that the two movements went hand in hand. In the south, opposition to child labor laws from the textile industry also inhibited the adoption of mother's pensions laws. The east was the exception, for it was in the east that private charities had become so politically powerful that they were able to oppose effectively the expansion of state power into their domain or influence. It was in the east, moreover, where the suspicion of state power was the greatest, for political machines were using state power to maintain their base of power, and reformers were suspicious that a new governmental program would similarly be used for these "corrupt" purposes. As a result, Drew finds that in many eastern states child labor legislation is adopted without subsequent adoption of mothers' pensions laws.

Drew argues successfully that most work on growth of the welfare state interprets its creation in a not very nuanced way, seeing the creation of welfare institutions as the product of modernization, the rise of the trade union movement, the competition between the two political parties, and/or the outgrowth of economic catastrophe. Drew points out that specific welfare institutions have their own particular history which is embedded in unique political and governmental contexts.

The dissertation is thus an original contribution to literature on the growth of the welfare state. The research is thorough, the presentation is clear, and the findings modify our understanding of the way in which an important institution of the modern state was created. His interpretation, moreover, could well have important implications for the development of welfare programs in the developing countries of the third world.

Edward S. Corwin Award, for the best doctoral dissertation completed and accepted during 1987 or 1988 in the field of public law.

Award Committee: Michael W. Combs, University of Nebraska-Lincoln, chair; David M. 
O'Brien, University of Virginia; Karen O'Connor, Emory University.

Recipient: Mark Graber, University of Texas at Austin.

Dissertation: "The Transformation of the Modern Constitutional Defense of Free Speech," submitted by Yale University.

\section{Dissertation Chair: Rogers Smith.}

Citation: There was keen competition, but the winner of the American Political Science Association's 1989 Edward S. Corwin Award for the best doctoral dissertation in the field of public law is Mark A. Graber. The dissertation is entitled. "The Transformation of the Modern Constitutional Defense of Free Speech," submitted by the Department of Political Science, Yale University. The members of the Committee agreed that Graber's study makes a significant contribution to the literature on the interrelatedness of the decisions of the Supreme Court and its commentators. Specially, the author documents and analyzes how the defense of free speech emerged following Reconstruction and during the Progressive era. Contrary to conventional wisdom, this study provides evidence that concern for free speech developed long before World War I. Graber, for example, unveils the writings of such thinkers as John W. Burgess, Theodore Schroeder, Ernst Freund, John Dewey, Roscoe Pound, and others. He suggests that these writers and their systems of analysis greatly influenced and shaped Zechariah Chafee's thoughts on freedom of speech: Graber, in turn, demonstrates how Chafee has had a profound impact upon the defense of freedom of speech and the Supreme Court's treatment of freedom of speech.

This is an outstanding study. One member of the Committee commented. "Mark has given us a study that shows the linkage between the [Supreme] Court and its commentators in the ongoing dialogue of constitutional law." In summary, the dissertation, "The Transformation of the Modern Constitutional Defense of Free Speech," is well conceived, effectively researched, brilliantly analyzed, and lucidly written.

Harold D. Lasswell Award, for the best doctoral dissertation completed and accepted during 1987 or 1988 in the field of policy studies (supported by the Policy Studies Organization).

Award Committee: Deborah Stone, Brandeis University, chair; Peter Cowhey, University of California, San Diego; and Wilbur C. Rich, Wayne State University.
Recipient: Carol Hager, University of California, San Diego.

Dissertation: "Technological Democracy: Bureaucracy and Citizenry in the West German Energy Debate," submitted by University of California, San Diego.

Dissertation Chair: David Laitin.

Recipient: John Mark Hansen, University of Chicago.

Dissertation: "Creating a New Politics: The Evolution of an Agricultural Policy Network in Congress, 1919-1980" submitted by Yale University.

\section{Dissertation Chair: David Mayhew.}

Citation: Carol Hager's dissertation speaks to one of the central problems of political science: What are the prospects for democratic participation in the modern technological state? Her research traces and interprets the conflict between bureaucratic and expert policy-making institutions and the citizenry of West Berlin over the issues of energy and environmental policy.

Hager's rich and illuminating study operates on several levels. It is a meticulous case study of a citizen protest group that crystallized around and in opposition to a proposed coal-fired power plant, and at the same time, it explores the broader dilemmas of citizen participation in policy arenas where technical expertise is the lingua franca. Hager demonstrates that citizen groups are motivated by two types of concerns-material or substantive demands (in this case, to preserve the Berlin forests), and political or process demands (in this case, to formulate energy policy in a way that allows participation of ordinary citizens and that gives weight to their concerns). She calls these two concerns "the policy problem" and "the legitimation problem," and her study is ultimately about how these two problems interact.

Hager found that the technicality of the energy debate was not a barrier to citizen par. ticipation. On the contrary, the citizen group was able to develop its own expertise and enter into the policy debates as a powerful player. She finds, in fact, that informed citizen participation actually improved the technical competence of the state planning apparatus. The group revealed the technical inadequacies of the data used by the state agencies, and revealed the degree to which the legislature was merely promoting the interests of the power company.

At the same time, citizen participation also forced a reform of policy making institutions. The citizen movement established alternative 
representative institutions, outside the Berlin parliament. It used the courts to wrest power from legislative bodies and to empower new oversight authorities. It formed a new party (with considerable success) to bring its concerns into parliament.

However, all was not roses. Participation in the technical planning processes of traditional institutions posed grave problems for the internal dynamics of the citizens' movement, because a significant portion of its members believed the traditional institutions were totally without legitimacy. Hager has a very subtle analysis of how the policy and strategy choices of the group affected its own internal conflict, and how the group's conflicts, in turn, affected the larger policy-making process. In the end, she concludes that the citizen movement must be judged not only on the policy outcomes it achieved, but on its ability to transform the process of policy decision-making. She convincingly demonstrates that the movement did foster development of a long-lasting participatory consciousness.

The dissertation is an optimistic and sophisticated contribution to democratic theory, as well as to our understanding of the ways that policy and politics shape each other.

John Mark Hansen seeks to explain when and why legislators grant high access to pressure groups. Under what conditions do interest groups, as opposed to parties, become the primary way of articulating policy agendas? Under what conditions do new ideas or groups with new ideas become enfranchised and their ideas become common wisdom?

Building on the analytical framework of the rational actor/public choice school, Hansen constructs an elegant theory. He postulates that legislators' primary goal is to get re-elected and that they are fundamentally risk-averse. They will grant access to the policy views of any intermediaries only when two conditions are met: (i) a new intermediary enjoys a competitive advantage over old ones in providing information about the policy demands of citizens and propaganda to influence the votes of citizens, and thus, in helping legislators to get re-elected; and (2) the competitive advantage in serving these tunctions is likely to recur in the future.

Hansen demonstrates the utility of this theory by examining the rise and fall of the farm lobby, particularly the American Farm Bureau, in the twentieth century. Elections in 1,924 and 1926 demonstrated the widespread popularity of the agricultural relief program that the farm groups promoted, and the realization that the farm depression was chronic convinced Midwestern legislators that the relief issue was recurrent. In the early thirties, Southern Democrats gained control of the Agricul. ture Committee and found that a coalition with the Midwestern Republicans on price supports would help their electoral position in the South.

The farm lobby enjoyed high access to Congress through about the mid-1950s, when conditions began to change. Hansen also has a theory about when policy networks change. Social, economic, demographic factors aiter the political environment, creating new uncertainty for legislators about what their constituents think and want. New potential intermediaries (perhaps political parties, perhaps old interest groups, and perhaps entirely new pressure groups) come into prominence and offer their advice. New groups are typically more specialized (such as crop lobbies) and can offer advice specifically tailored to a legislator's district. Legislators wait for electoral evidence that new groups can serve their information and propaganda needs, and ultimately their re-election goals. They. also look for evidence that the issues on which the new groups offer advice will be recurrent.

in the 1950s, these conditions were met and the old policy network broke down. The poor performance of Republicans in elections in the Midwest convinced Democratic legislators that the Farm Bureau program could not deliver as much electoral strength as partisan appeals. Moreover, the Farm Bureau's devotion to a program mostly aimed at corn growers made Southern Democrats less willing to cooperate in the logrolls necessary to get programs for their constituents. The Farm Bureau lost access, and in its place commodity-based organizations gained.

The dissertation is exceptionally well-crafted and beautifully written, and is an imaginative explanation of the dynamics of policy subsystems.

Helen Dwight Reid Award, for the best doctoral dissertation completed and accepted during 1987 or 1988 in the field of international relations, law and politics.

Award Committee: Lloyd Etheredge, Duke University, chair; Margaret P. Karns, University of Dayton; and Dwain Mefford, Ohio State University.

\section{Recipient: Yossi Shain, Tel Aviv University.}

Dissertation: "In Search of Loyalty and Recog. nition: The Political Activities of Exiles," submitted by Yale University.

\section{Dissertation Chair: Juan Linz.}

Citation: Yossi Shain's dissertation, In Search of Loyalty and Recognition: The Political Activity of Exiles, deals with a little-studied phenomenon that lies at the intersection of international rela- 
tions and comparative politics. His wide-ranging historical and contemporary discussion of exile political activities demonstrates how consequential exile groups can become to effect domestic regime changes in the 19th and 20th centuries.

The dissertation provides original conceptual development and analysis of both the external activities and internal politics of exile organizations. Shain's discussion of the problems of political legitimacy, loyalty, and recognition contributes new insights for political theory and international law, particularly in analyzing the dilemmas of loyalty at a distance.

In Search of Loyolty and Recognition: The Political Activity of Exiles is path-breaking in the field of international politics, raising intriguing questions for future work on the role of political exile groups as international non-governmental organizations (INGO's), their impact on government to government relations, and the dilemmas posed to both governments and intergovernmental organizations by the existence and activities of exile groups. Shain provides a wealth of illustrative material drawing upon exile groups as diverse as the Russian exiles of the 1920s, the Spanish Republicans, Italian exiles, and the Ayatolleh Khomeini.

Thus, Yossi Shain's dissertation is an inspired blend of historical case material and theory construction. It is both original and scientifically cumulative in the best sense, drawing upon the work of other scholars and inviting further investigation and theory-building about an important source of value conflict and change in world politics.

E. E. Schattschneider Award, for the best doctoral dissertation completed and accepted during 1987 or 1988 in the field of American government.

Award Committee: Kay Scholozman, Boston College, chair; Stephen Skowronek, Yale University; and Charles Stewart III. Masachusetts Institute of Technology.

Recipient: Victoria C. Hattam, Yale University.

Dissertation: "Unions and Politics: The Courts and American Labor: 1806-1896," submitted by the Massachusetts Institute of Technology.

\section{Dissertatin Chair: Suzanne Berger.}

Citation: The members of the E. E. Schattschneider Award Committee have agreed unanimously to award the 1989 prize for the best doctoral dissertation in the field of American government and politics to Victoria C. Hattam, whose dissertation, "Unions and Politics: The Courts and American Labor, 1806-1896," was completed at Massachusetts Institute of Technology under the direction of Suzanne Berger. This extremely well-written dissertation proposes a fresh solution to a puzzle that has absorbed social scientists for decades, the sources of American exceptionalism. In the era of the risk-averse dissertation, it is impressive to read a work that dares to offer a re-interpretation of a problem of such obvious weight, especially one that not only uses historical data but also introduces comparative material. In making a complex argument, Ms. Hattam never loses sight of her intellectual prey; the links between the empirical details and the larger question at stake are made clear throughout.

In explaining the unique strategy pursued by organized labor in America, Hattam reframes the classic question, "Why no socialism?" maintaining that the really interesting question is "Why no socialist party?" She makes a case that the American labor movement was characterized in its early years by a tradition of protest quite similar to the pattern in Europe. In the late nineteenth century, however, the American labor movement diverged from the path taken by organized labor in Europe. What distinguished American unions was not that they were less radical than their European counterparts, but rather that they concentrated almost solely on negotiations with employers, eschewing political strategies, especially electoral and party politics. According to Hattam, this distinctive amalgam of industrial militance and political quiescence should not be explained by the factors ordinarily adduced to explain American exceptionalism-the dominance of Lockean liberal ideology in America, the ethnic diversity of the American working class, the relative affluence of American workers. She attributes this outcome, on the contrary, to the structure and policies of the American state, in particular, the dominance of the courts in regulating labor.

Hattam argues that the effect of judicial hostility to organizations of workers in the postCivil War period was not to determine whether American labor would be radical or reformist but rather to foreclose political action as a viable strategy for improving the lot of workers. Early in the nineteenth century, American courts, anxious to establish their authority in the newly constituted republic, invoked the common law doctrine of criminal conspiracy to convict striking workers and regulate industrial conflict. When the courts resumed this practice after the Civil War, the state legislatures of New York and Pennsylvania - with the support of workers' organizations-passed anti-conspiracy legislation protecting workers' right to organize and act col. 
lectively. This legislation, however, proved no remedy. In contrast to the English courts, which were much more deferential to Parliament, the American courts evaded these laws by continuing to convict workers of conspiracy and, later, suppressing industrial conflict through use of the injunction. Thus, the insulation of the courts from democratic control deprived American workers of the fruits of their legislative victories. In short, according to Hattam, the ability of the judiciary to undermine clear legislative directives demonstrated to American labor the futility of political strategies and the wisdom of channeling their efforts away from electoral and party politics. Hence, no socialist party in America.

Leo Strauss Award, for the best doctoral dissertation completed and accepted during 1987 or 1988 in the field of political philosophy.

Award Committee: Jean Bethke Elshtain, Vanderbilt University, chair; Hadley Arkes, Amherst College: and Joshua Cohen. Masachusetts Institute of Technology.

\section{Recipient: Tai-Shuenn Yang. National Cheng-} Chi University.

Dissertation: "Property Rights and Constitution Order in Imperial China," submitted by Indiana University.

\section{Dissertation Chairs: Vincent Ostrom and Jean Robinson.}

Citation: Political philosophy is a diverse enterprise as this year's nominated dissertations for the Leo Strauss Award demonstrate. Among political philosophers there are ontological, epistemological, hermeneutical and numerous other contested matters. This makes the work of a Committee to select the best dissertation in political philosophy a vexing and timeconsuming task. The Committee this year found itself on disagreement at many points during its deliberations. Eventually, and after many hours of discussion, we decided to offer the award this year to Tai-Shuenn Yang of Indiana University.

Tai-Shuenn Yang's dissertation, "Property Rights and Constitutional Order in Imperial China," is a model of concision and an excellent piece of scholarship. It sustains a coherent, focused and interesting argument over a wide range of materials. His elaboration of property rights, understandings of the nature of contract, and the implications for economic and political development of Chinese village autonomy and familialism are compellingly argued and encourage the reader to draw contrasts with the Western tradition at each point along the way. His is a close examination of the rela- tionship between property rights and traditional Chinese institutions. Although Committee members agreed that his argument would have been enhanced were explicit attention paid to the moral implications of the logic of "freedom of contract." each of us learned much from his exposition and the clarity with which it was presented. The Committee also appreciated Tai-Shuenn Yang's independent writing. Even when he was drawing on the views of others, he presented issues in his own voice.

Given the current turmoil in China and the embrace by protestors of the Western language of democracy, freedom, and rights, a dissertation that helps us to situate these concerns historically and to evaluate the possibilities for transformation in the Chinese system. is an important and worthy contribution.

Leonard $\mathrm{D}$. White Award, for the best doctoral dissertation completed and accepted during 1987 or 1988 in the field of public administration, including broadly related problems of policy formation and administrative theory.

Award Committee: David Olson, University of Washington, chair; Terry Moe, Stanford University; and Irene Rubin, Northern Illinois University.

\section{Recipient: Roy T. Meyers, Congressional} Budget Office.

Dissertation: "Microbudgetary Strategies and Outcomes," submitted by the University of Michigan.

\section{Dissertation Chair: John Kingdon.}

Citation: Incrementalism has dominated theorizing about the process by which budgetary resources are allocated to individual programs and agencies for the past quarter century. With its assumptions of bounded rationality and mutual adjustment under conditions of uncertainty, incrementalism advanced a theory of the budgetary process featuring concensual bargaining among institutions, settled roles and strategies among participants, and stable, incremental patterns of outcomes over time. Roy $T$. Meyers forcefully challenges the conceptual utility, empirical validity, and normative implications of incrementalist theory in his dissertation "Microbudgetary Strategies and Competition." By contrast, Meyers offers an alternative understanding of budgetary processes which emphasizes its complexity, wherein critical structural characteristics create strategic opportunities, and where participants compete for scarce budgetary resources and thereby develop unstable roles. The strategies available to budget participants are then clearly outlined 
and applied in a series of case studies to several agencies and programs.

An initial task for Meyers is to understand budgetary numbers, how they are assembled, and how they are presented as "official." He begins with the bold assertion that reliance on official government-reported budgetary data leads to irrelevant and often spurious conclusions because such data are frequently flawed and as often incomplete. His detailed discussion identifies numerous ways in which official numbers are neither reliable nor valid for scientific inquiry. Traditonal budgetary analyses based simply upon annual appropriations figures fail to account for off budget programs, discretionary funds, unreported costs, supplemental appropriations, rescissions, continuing resolutions, loan guarantees, tax expenditures, and critical time components of spending processes, to list but a few of the potential flaws. Meyers' intimate knowledge of national budgetary proceedings (he was a Congressional Budget Office analyst through the 1980s) leads him to reject the simple budgetary models based upon annual appropriations figures. By pealing away the many layers of the budgetary onion he is able to distinguish between reported budgetary outcomes, which are highly visible and readily available, and the more complex, detailed, and finely grained real outcomes which are often hidden in ingeneous accounting formats, complex program elements, and masked by critical timing events.

Meyers provides a more general contribution by developing a structural strategy theory of budgeting. The budgetary history of selected agencies is reviewed in order to construct a model of budgetary strategies employed by participants in the process. The theory is based upon four structural budgetary characteristics which interact with institutional settings to affect budgetary outcomes. The budgetary characteristics of accounting practices, decision processes, policy designs, and perceived program effects create strategic opportunities which can advantage or disadvantage agencies and their programs. In turn, budgetary participants adopt strategies in response to the key characteristics of the process in their attempts to obtain guaranteed sources of financing as well as to avoid budgetary controls over their programs. Strategic participant behavior creates competition between agencies which have recourse to differing political resources and display varying political skills in identifying their st ategic opportunities and taking advantage of them. The model Meyers forwards is densely informed by the complexities of the budgetary process and it provides a plausible alternative to the dominant incrementalist interpretation.
This dissertation provides a stimulating critique of earlier scholarship on the budgetary process and a provocative challenge to the reliability and validity of government-supplied numbers from which current and future scholars can benefit. It advances a strategic theory of budgeting based upon structural characteristics of the budgetary process that themselves have experienced significant change in the past decade. The study breaks new ground in budgetary research, points the way for future research, and forwards applied recommendations for reforming the process.

\section{PAPER AND ARTICLE AWARDS}

Franklin L. Burdette Pi Sigma Alpha Award $(\$ 250)$, for the best paper presented at the 1988 Annual Meeting.

Award Committee: John R. Freeman, University of Minnesota, chair; Marilyn Hoskin. State University of New York, Buffalo; and Herbert Weisberg, Ohio State University.

Recipients: George Rabinowitz, Stuart Elaine Macdonald, University of North Carolina; Ola Listhaug, University of Trondheim.

Paper: "New Players in an Old Game."

Citation: Rabinowitz, Macdonald and Listhaug address the question of what explains the electoral success or failure of political parties in democracies. More specifically, they examine the relationship between the spatial position of parties and the extent to which those parties are able to garner electoral support. When it makes clear predictions, traditional proximity theory implies that most parties will move to the position where the distribution of voters is most dense. Rabinowitz, Macdonald and Listhaug develop an alternative account of party behavior, direction theory, which leads to a different prediction: that parties will locate in a circle-on the boundary of a "region of party acceptability" -at a moderate distance from the location where the distribution of voters is most dense. In this context they also derive a competing explanation for the behavior and electoral performance of new parties. Rabinowitz, Macdonald and Listhaug proceed to show that direction theory better accounts for the Norwegian and Swedish experiences than traditional proximity theory. They demonstrate that in both countries parties locate, as direction theory predicts, around rather than in the location where the voters are most dense. The connection between and implications of direction theory for Sartori's analysis of moderate and polarized pluralism are explored by the authors in the conclusion of their paper. 
Rabinowitz, Macdonald, and Listhaug's investigation is a well crafted and important piece of research. The paper is grounded in both theory and substance. The tenets of traditional proximity theory are carefully delineated and a fair test of those tenets is devised. Direction theory is derived from existing and new theoretical work on party systems and voting behavior. The entire theoretical exercise is informed by recent political developments in Norway and Sweden. for example, by changes in voters' support for extreme parties in the two countries.

Rabinowitz, Macdonald, and Listhaug's analysis is quite rigorous. They clearly show how traditional proximity and direction theories produce different expectations about how parties behave. And they construct a research design that allows for a meaningful test of these competing theoretical expectations. In analyzing their data, Rabinowitz, Macdonald, and Listhaug are sensitive to various methodological issues. As a consequence, they convince the reader that their results for the Norwegian and Swedish party systems are accurate. These results show the relative superiority of direction theory over traditional proximity theory. Direction theory emerges as a clear advance in our understanding of party systems. Some of the authors' findings such as the unidimensional character of the Swedish party system prior to 1982 pose challenges for students of party systems. Proponents of proximity and other theories will have to explain these and other empirical patterns which Rabinowitz, Macdonald and Listhaug have uncovered. Finally, the authors suggestions for future research appear to be quite promising. The incorporation of direction theory in theories of political stability may well yield an improved understanding of why some democracies survive while others perish.

The American Political Science Association is pleased to honor George Rabinowitz, Stuart Elaine Macdonald, and Ola Listhaug for this very impressive and important contribution to the study of party systems.

Honorable Mention-Charles Franklin, Washington University-St. Louis, "Two Stage Auxiliary Instrumental Variables Estimation;" Robert Powell, Harvard University, "Nuclear Deterrence and the Strategy of Limited Retaliation."

Heinz Eulau Award (\$500), for the best article published in The American Political Science Review during 1988.

Award Committee: Charles $O$. Jones, University of Wisconsin, Madison, chair; Henry Brady,
University of Chicago; and Gerhard Loewenberg. University of lowa.

Recipient: James L. Gibson, University of Houston.

Article: "Political Intolerance and Political Repression During the McCarthy Red Scare," June, 1988 APSR.

Citation: The Committee read the 43 articles in Volume 82 of the American Political Science Review.

Professor Gibson states that "I have discovered no evidence that political repression in the U.S. states stems from demands from ordinary citizens to curtail the rights and activities of unpopular political authorities." In this wellcrafted, interesting, and important article. Professor Gibson examines the effects of elite and mass opinion on repressive public policy in the states. He draws on the 1954 Stouffer survey. imaginatively developing a means for identifying states of residence of the respondents. His findings challenge an elitist theory of democracy that leads one to expect intolerant masses and moderating elites. The article is fully deserving of the Award. It is in the best tradition of the work of Professor Heinz Eulau.

\section{BOOK AWARDS}

Ralph J. Bunche Award ( $\$ 500)$, for the best scholarly work in political science published in 1988 which explores the phenomenon of ethnic and cultural pluralism.

Award Committee: John Mollenkopf, City University of New York, chair; Walker Connor, Trinity College; and Hanes Walton, Savannah State College.

Recipient: Ronald Walter. Howard University.

Book: Black Presidential Politics in America: A Strotegic Approoch, published by the State University of New York Press.

Citation: In Black. Presidential Politics in America. Ronald Walters illuminates the difficult strategic choices facing African-Americans political leaders and voters as they seek to influence presidential elections and public policy. While acknowledging that our imperfect social contract has relegated black people to permanent minority status. Walters is not content to blame the system. Instead, he analyzes how black political choices might contribute to, or overcome, this situation.

After carefully reviewing the historical and egional dimensions of black political mobilization. Walters concludes that African-American voters and their leaders have adopted a strat- 
egy of "dependent leverage." This strategy seeks to gain advantage by committing black votes to the Democratic party in return for policy rewards. Waiters finds this strategy wanting. Applying for insight from game theory that the last actor to join in forming a majority coalition wields the greatest influence, he argues instead that blacks should follow an "independent leverage" strategy in which they seek to exercise the balance of power between the two parties. Walters' challenge to incumbent black elected officials' attachment to white political elites and to white elected leaders reliance on consistent black support, while controversial, urges us to go beyond conventional thinking. As such, Black Presidential Politics in Americo makes an insightful and compelling contribution to the tradition of scholarly activism.

Honorable mention is also made of Dianne Pinderhughes, Roce and Ethnicity in Chicago Politics, for its critical re-examination of the theory of ethnic pluralism.

Gladys M. Kammerer Award $(\$ 1,000)$, for the best political science publication in 1988 in the field of U.S. national policy.

Award Committee: Barbara Sinclair, University of California, Riverside, chair: Anthony King, University of Essex; and Robert Salisbury, Washington University.

Recipient: Thomas J. Anton, Brown University.

Book: American Federalism and Public Policy: How the System works, published by Random House and Temple University Press.

Citation: In American Federalism and Public Policy: How the System Works. Thomas Anton analytically synthesizes a vast array of material on a familiar but badly underexamined topic. Students of American politics regularly give lip service to the importance of the system being federal in structure and the states along with their local governments playing a major role in shaping the outcomes of public policy. Only a small fraction of those who acknowledge the importance of federalism, however, actually examine its effects in detail. Thomas Anton has demonstrated that federalism is not only important but can provide the material for exemplary social science.

Anton's synthesis draws from previous research a much enhanced understanding of the phenomenon and it provides useful concepts and directions for future research. It also focuses our attention on the basically political character of federalism and on the need for a politics-centered framework to understand it.

Anton orders and shapes previous research into patterns that make sense of the diversity and dynamism of American federalism. Rejecting both the temptation to see only variety and flux and the temptation to impose a sterile order that obscures rather than illuminates, he finds a theoretically and empirically sensible middle ground in the notion of benefit coalitions. He postulates a dynamic process of benefit coalition construction leading to a surge of policy innovation, followed by expansion of those support coalitions to the point of enervation and possible "reform" leading to a new cycle. The benefit coalition framework centers our attention on the basic political issue to the processes through which individuals and groups mobilize support for government programs. It thus reaffirms that the fundamental questions about how American federalism works that we as political scientists want to be able to answer are questions about political processes and provides us with a framework well suited to exploring such questions.

Benjamin E. Lippincott Award $(\$ 1,500)$, for a work of exceptional quality by a living political theorist that is still considered significant after a time span of at least 15 years since the original publication; awarded biennially.

Award Committee: Austin Ranney, University of California, Berkeley, chair; Harry Eckstein, University of California, Irvine; and Robert Gilpin, Princeton University.

\section{Recipient: Robert A. Dahl, Yale University.}

Book: A Preface to Democratic Theony, University of Chicago Press, 1956.

Citation: The Benjamin Evans Lippincott Award is given biennially to honor "a work of exceptional quality by a living political theorist that is still considered significant after a time span of at least fifteen years since the original publication." The award committee for 1989 was composed of Harry Eckstein, Robert Gilpin, and Austin Ranney, who served as chair. We are pleased to announce that the 1989 award is presented to Robert A. Dahl for his book A Prefoce to Democratic Theory, first given as the Charles B. Walgreen Foundation lectures at the University of Chicago and published by the University of Chicago Press in 1956.

We can state briefly and summarily why Dahl's book fulfills two of the three criteria for the award: First, its author is still very much alive and still writing on the problems of democratic theory that have concerned him all his life. Second, A Preface to Democratic Theory is still widely regarded as one of the most significant works ever written on the topic, and while more recent works on democratic theory, such as those by Peter Bachrach, Benjamin Barber, 
Harry Eckstein. Adrienne Koch. Carole Pateman, Giovanni Sartori, and Elaine Spitz, have not all agreed with Dahl's conclusions, all have felt compelled to deal with them one way or another.

The third criterion, exceptional quality, poses more difficult and more interesting questions. We feel that a book of excellent quality in political theory (or any other field) should meet at least three standards: First, it should deal with important questions. Second, it should examine those questions with both rigorous logic and a full and fair consideration of the merits and demerits of competing answers. And third, it should stimulate and enrich further work on its concerns. A Preface to Democratic Theory, we believe, meets all three standards superbly. Many readers have found many virtues in the book, but in this citation we will focus on three contributions we find especially valuable.

The first is the book's approach to its materials, a rich blend of close textual analysis of his own ideas as well as those of other writers, using whatever analytical tools-axiomatic theory, empirical observation, and the logical relations among propositions - he finds appropriate for the question at hand. For example, in setting forth what he calls "the Madisonian theory of democracy, " Dahl does not merely string together a series of quotations from The Federalist papers; rather, as he explains:

It would be misleading to ascribe all the propositions that follow directly to James Madison himself. ... . [for] even Madison did not always articulate his assumptions as to fact, definition, or value. I have therefore found it necessary from time to time to supply what seem to me these implied assumptions. This is a risky business, and in defense I can only say that in every instance I have sought to make his position as orderly and coherent as possible and not to weaken it. in brief, I rely on Madison where he seems to make his own case most logical, consistent, and explicit, but in all other cases I try to formulate a proposition that seems to me more logical, consistent, and explicit. It is a style of argument I am concerned with, not a perfect reproduction of Madison's words. (pp. 4-5)

Dahl is as good as his word. He concludes that Madison's defense of the separation of powers rests upon the assertion that the accumulation of all powers in one set of hands is tyranny, but notes that Madison nowhere states why tyranny is evil. So he reconstructs Madison's argument by asking which of its propositions are explicit and which are implicit, by making explicit those that are implicit, by ex. amining how they relate to one another, by specifying which are axiomatic and which are empirically verifiable, and by asking how Madison verifies them and whether they can be verified by other kinds of observations. Dahl continues. "To keep the Madisonian system intact, I took the liberty of specifying what these consequences must be, namely, 'the severe deprivation of natural rights. " "(p. 12)

It can also be said of Dahl's methods that he was one of the first political scientists to use formal theory and even the notational language of symbolic logic in an effort to lessen the ambiguities about the meaning of concepts and the logical relations of ideas in democratic theory. One example is the simple definition of the principle of majority rule with which he opens his discussion of the anti-Madisonian "Populistic" theory of democracy:

The principle of majority rule prescribes that in choosing among alternatives, the alternative preferred by the greater number is selected. That is, given two or more alternatives $x, y$, etc., in order for $x$ to be government policy it is a necessary and sufficient condition that the number who prefer $x$ to any alternative is greater than the number who prefer any single alternative to $x$. (pp. 37-38)

Another example is the footnote in which he suggests that "symbolically, the Rule may be stated as follows:

$\operatorname{NP}(x, y)>N P(y, x)-x P g y$ where $x P g y$ means " $x$ is preferred by governments to $y$ " or " $x$ rather than $y$ is chosen as government policy." (footnote 6, p. 39). Many readers of the Prefoce in 1956 found such statements incomprehensible, and some even found them offensive. But most theorists of democracy in the 1990s find them both comprehensible and useful, in no small part because of Dahl's early and unthreatening introduction of such language into the discourse of political theory.

Yet Dahl, like all great political theorists, regards method as the servant of substance, and The Prefoce to Democratic Theory has had perhaps its greatest impact in three areas: its discussion of the intensity problem, its introduction of the concept of "polyarchy," and its demonstration of how abstract theoretical models can contribute to the analysis of real-life polities.

Dahl begins his analysis of polyarchy by noting that "there is no democratic theory - there are only democratic theories." (p. I) After his examination of two such theories, the Madisonian and the Populistic, he suggests that there are two ways in which we might construct a more generally accepted and therefore more useful 
theory of democracy. One is maximization: We could specify a set of goals to be maximized. such as majority rule or political equality, and define democracy in terms of the specitic governmental institutions and processes necessary to maximize those goals. But, he says, there is a better way:

A second way--this one might be called the descriptive method-is to consider as a single class of phenomena all those nation states and social organizations that are commonly called democratic by political scientists, and by examining the members of this class to discover, first, the distinguishing characteristics they have in common, and. second, the necessary and sufficient conditions for social organizations possessing these characteristics. ( $p .63$ )

Dahl then sets forth eight conditions that add up to a Weberian ideal type of democracy. conditions that might be used as benchmarks against which actual polities can be measured. $\mathrm{He}$ then suggests that if we reserve the word "democracy" for the perfect realization of all the conditions and freely admit that no actual polity ever has or ever will fully match them, they can nevertheless be used to make important statements about real-life polities:

Because numan organizations rarely and perhaps never reach the limit set by these eight conditions, it is necessary to interpret each of the conditions as one end of a continuum or scale along which any given organization might be measured. Unfortunately there is at present no known way of assigning meaningful weights to the eight conditions. However, even without weights, if the eight scales could each be metricized, it would be possible and perhaps useful to establish some arbitrary but not meaningless classes of which the upper chunk might be called "polyarchies." (pp. 73-74)

Dahl opens his exploration of the intensity problem by noting a critical difficulty with the majority principle: Starting from the premises of popular sovereignty and political equality, strict logic requires that all decisions be made according to that principle. However, "by making 'most preferred' equivalent to 'preferred by the most' we deliberately bypassed a crucial problem: What if the minority prefers its alternative much more passionately than the majority prefers a contrary alternative. Does the majority principle still make sense?" (p. 90) He then canvasses the difficult problems involved in measuring different intensities accurately enough to take them into account in making decisions, and concludes that such measures can. at best, be only rough and approximate. And he observes that the traditional American devices for protecting intense minorities from being overridden by less intense majorities, such as judicial review and equal representation of the States in the Senate, cannot be justified by pure logic; indeed, "no solution to the intensity problem through constitutional or proced. ural rules is attainable." (p. 119) But he takes most of the sting out of this conclusion by observing that the ways in which decisions are actually made in the United States usually, though not always, make the problem more difficult in theory than in practice:

Thus the making of governmental decisions is not a majestic march of great majorities united upon certain matters of basic policy, It is the steady appeasement of relatively small groups. Even when these groups add up to a numerical majority at election time it is usually not useful to construe the majority as more than an arithmetic expression. For to an extent that would have pleased Madison enormously, the numerical majority is incapable of undertaking any coordinated action. It is the various compo. nents of the numerical majority that have the means for action. (p. 146)

Thus Dahl's analysis of the intensity problem. like the rest of his book, has stimulated a generation of theorists of democracy to think more clearly about the great questions, and many of his conclusions encourage us to think that our practice may be better than our theory.

Dahl's book has performed, and continues to perform, the most critical function that Max Weber assigned to social science vis-a-vis politics and, indeed, itself: relentless clarification, where others content themselves with vagueness and platitudes.

$A$ book that thus continues both to stimulate and reassure its readers more than three decades after its publication richly deserves the award we are pleased and proud to present here to Robert A. Dahl for A Preface to Democratic Theory.

$$
\begin{aligned}
& \text { Harry Eckstein } \\
& \text { Robert Gilpin } \\
& \text { Austin Ranney }
\end{aligned}
$$

Victoria Schuck Award (\$500), for the best book published in 1987 or 1988 on women and politics.

Award Committee: Mary Fainsod Katzenstein. Cornell University, chair; Janet Boles. Marquette University; and Janet Flammang, University of Santa Clara.

Recipient: Zillah Eisenstein, Ithaca College. 
Book: The Female Body and the Law, published by the University of California Press, Berkeley.

Recipient: Carole Pateman, University of Sydney.

Book: The Sexual Contract, published by Stanford University Press.

Citation: Zillah Eisenstein The Female Body and the Low. University of California, Berkeley. Like so much of Zillah Eisenstein's previous work. this highly original study opens up new scholarly territory. Applying the insights of deconstruction to the intricacies of case law. Eisenstein crafts a powerful yet subtle analysis of the legal treatment of sex equality. Arguing that past and current law presumes the norm of the male body, Eisenstein challenges us to search out plural standards that recognize sexual and bodily difference. The Female Body and the Low casts debates about surrogacy, pregnancy leave, reproductive rights and other vital contemporary issues in a creative and compelling new framework.

Carol Pateman, The Sexual Contract, Stanford University Press. In The Sexual Contract Carole Pateman offers a provocative and vigorous critique of contract as a principle of social organization. She argues that contractual arrangements such as citizenship and employment, marriage and prostitution are not agreements freely entered into by equal individuals but originate within a system of male domination and female subordination. Her wide-ranging erudition brings these arguments to bear on both the classical contract tradition and its contemporary variants. Pateman's keen analysis of the contradictions surrounding contract theory directs us to reconsider the origins of our commitments to liberal rights and freedoms.

Woodrow Wilson Foundation Award $(\$ 2,000)$, for the best book published in the U.S. during 1988 on government, politics or international affairs.

Award Committee: Samuel H. Barnes, University of Michigan, chair; Walter Dean Burnham, University of Texas at Austin; and Frank Sorauf, University of Minnesota.

Recipient: Larry Bartels, University of Rochester.

Book: Presidential Primaries and the Dynamics of Public Choice, published by Princeton University Press.

Citation: Presidential Primories and the Dynamics of Public Choice is a stimulating example of the cumulative achievements of political science as a discipline. It merges, in a very effective and often elegant manner, theory and data from the intellectual traditions of both rational choice and the study of political behavior. Bartels is unusually creative in selecting a variety of data and diverse analytical techniques appropriate for examining the dynamic aspects of presidential primaries. The book is the definitive treatment of momentum in presidential campaigns-big mo-but it is much more than this. It combines rational choice ideas with the data and concerns of the study of electoral politics to show that the primary process itself, through its sequential and cumulative decisions, resolves several conceptual problems of great relevance to democratic and empirical theory.

Bartels places rational choice thinking in the dynamic context of primary campaigns. He uses an extensive body of survey, voting, and media exposure data to examine preference formation and change over the course of the campaigns. He shows that a candidate's actual performance is evaluated against public, especially media, expectations; achievements are largely discounted if anticipated. The media's need for excitement has a substantial impact on the outcomes. Preferences are thus not static but rather change as information increases and credible choices are narrowed.

The book contributes to democratic theory through its sophisticated treatment of the paradox of voting. Bartels shows that the accumulation of information week-by-week relaxes the constraints on majority formation treated by the Arrow problem. The changing visibility of candidates, their performance in the "horse race" aspects of the campaign, and their increasing and decreasing credibility add up to massive societal learning that progressively narrows and focuses effective choice. Therefore, in Bartel's view, electoral reforms establishing a national primary or a system of regional primaries would have the likely consequences of complicating and greatly inhibiting the achievement of effective consensus within parties. Thus Presidential Primaries and the Dynamics of Public Choice is not only a first rate account of the empirical workings of the contemporary nominee selection process. It also contributes to theoretical understanding by demonstrating the important role that electoral institutions play in the formation of preferences and in the structuring of alternatives.

\section{CAREER AWARDS}

John Gaus Award $(\$ 1,500)$. The John Gaus Distinguished Lecturer is to honor the recipient's lifetime of exemplary scholarship in the joint tradition of political science and public administration and, more generally, to recognize 
achievement and encourage scholarship in public administration.

Award Committee: Joseph LaPalombara, Yale University, chair; James Carroll, Brookings Institution; and Beryl Radin, Washington Public Affairs Center.

Recipient: Aaron Wildavsky, University of California, Berkeley.

Lecture (was at 5:30 p.m. Friday, September I. Ballroom A) "Joseph the Administrator."

Citation: The John Gaus Award is presented annually to a scholar whose work reflects the highest standards of our profession, and also explicates the relationship between political science and public administration. Few have achieved this unusual blend more impressively than has Aaron Wildavsky. This is apparent not just in his remarkable scholarly output; it is reflected as well in the administrative and intellectual leadership he has offered his university, this and other professional associations, and organizations in the non-profit sector.

For three decades, Aaron Wildavsky has provided us with often trail-blazing works that have given precise meaning and impressive explanatory power to the concept of culture-as it applies to organizations and institutions, to the behavior of those who man these human artifacts, and to the broader historical and spatial contexts in which men and their institutions evolve. Whether writing about pollution or taxation, public health or natural resources, human entitlements or efficiency, Wildavsky can be counted on to improve our theoretical as well as empirical understanding of the complex interplay among perceptions, preferences, options, choices, implementations and outcomes.

From the beginning, Aaron Wildavsky has ventured into aspects of the process of government shunned by a generation of his colleagues who were more comfortable with inputs rather than with outputs, and has clarified murky and complex intermediate steps that convert inputs into more or less successful public policy. Always provocative, and with little tolerance for foolishness, he has challenged us all to reach for a higher standard.

We owe to his research and insights a quantum improvement in our knowledge of the budgetary process and its nuances, not only in the U.S. but in other polities as well. But the work of this astonishing productive scholar has ranged over political science and public administration, contributing as well to our understanding of presidential elections, policy analysis, program implementation, local government, developing countries, administrative history from its birth to the present, and much more. On many occasions, he has collaborated with younger scholars, whose names invariably appear first on the title page. The breadth of his scholarly output is attested by his having in the past received the Harold Lasswell. Dwight Waldo, and Paul Lazersfeld awards.

Aaron Wildavsky has brought to his professional role qualities that John Gaus shared originality of thought, an abiding concern for the health of the body politic, and a graceful style of expression. Often an agenda setter in the fields he touches, seminal seems a word invented for such as he. In grateful recognition of his distinction as a weaver of the interlacing strands of political science and public administration, the Association confers on him the John Gaus Award.

Hubert H. Humphrey Award $(\$ 500)$, presented each year in recognition of notable public service by a political scientist.

Award Committee: Norman J. Ornstein, American Enterprise Institute, chair; David Denoon, New York University; and Jeanie R. Stanley, University of Texas at Tyler.

Recipient: Brent Scowcroft, special assistant to the president for National Security Affarrs, The White House.

Citation: The Hubert $\mathrm{H}$. Humphrey Award is presented every year in recognition of notable public service by a political scientist.

General Brent Scowcroft is today well known for establishirg and reestablishing the most succcessful model for the role of the National Security Council in the National Security Advisor in the policy process since they were established in 1947. He is not as widely known for his credentials and career as a political scientistwhich include, incidentally, long-standing and active membership in the APSA. Yet from the day he left Ogden, Utah, for West Point at the height of World War II, Scoweroft has moved often and gracefully between active service to our nation and the worlds of academia and scholarship. Indeed, one could argue that his remarkable success in the second-most-difficult job at the White House is a reflection of the best traits of Scowcroft as political scientistregard for institutions, respect for scholarship over rigid ideology, an appreciation for coalitions and consensus, and an understanding of the delicacy and subtlety of international affairs.

Between his service to President Ford and President Bush, Scowcroft stepped in several times to provide the government with a balanced, analytical and practical assessment of a policy impasse. In 1983, a panel he headed stepped in to resolve a contentious and highly controversial dispute over the deployment and 
basing of mobile missiles, and came up with a bipartisan plan that was at once strategically sound and politically feasible.

More recently, as a member of the Tower Commission examining the Iran-Contra scandal, he helped produce an invaluable case study of decision-making in the executive branch during the 1980s. Although the panel completed its work in just three months, its report still provides students of government with the clearest view of what went wrong in American foreign policy in 1985 and 1986. Incidentally, the report also prompted the National Security Council to return to the role Scowcroft had established for it in 1975: in the words of Strategic Review, an "honest broker, coordinator and manager of interagency cooperation."

The simultaneous dedication to scholarship and service is nothing new for Brent Scowcroft. He entered the Army in 1943, and went to West Point, graduating in 1947. After pilot training and several operational positions, he obtained a master's degree from Columbia and returned to West Point to teach Russian history in the Department of Social Sciences. Six years later, he was a military attache in our Belgrade, Yugoslavia embassy, but when he returned to the United States in 1962, it was to be a professor and later (acting) head of the political science department at the Air Force Academy. At the same time, he completed his doctorate in international relations at Columbia.

in 1967. he embarked on the procession of jobs that would lead him to the White House. Scowcroft went to work at Air Force headquarters doing long-range strategic planning. He moved rapidly up the ranks of the Air Force and the Defense Department, becoming the Special Assistant to the Director of the Joint Chiefs of Staff, then Military Assistant to the President, then Deputy National Security Advisor. In 1975, he took over from Henry Kissinger as national security adviser.

Even as he occupied some of the most demanding and important posts in our public service, Brent Scowcroft kept up his ties to the academic world, both formal-membership in the APSA and on the Advisory Council of the johns Hopkins School of Advanced Internation. al Studies-and informal-through participation in annual meetings and countless seminars and roundtables. In the mold of Hubert Humphrey, Scowcroft is a skilled practitioner in the world of public policy, yet is comfortable in the world of academia and in the presence of academics. More than most, he appreciates the relation. ship between sound scholarship and analysis and good governing.

We cannot all expect to have General Scowcroft's boundless energy and the remarkable character that led George Bush, on nominating him, to recall that, "I worked for Brent when I was director of central intelligence. " But just as he established the model for the successful NCS, Scowcroft serves political scientists as the model of how we can best bring our training to the practice of government. A sense of history. an understanding of the purpose, role and legitimacy of institutions, and a recognition that those institutions must outlive the individuals running them often seem rare attributes in gov. ernment. In bringing them to the practice of American foreign policy, General Brent Scowcroft has righted the ship of state more than once. For showing us as students of politics how we can actually make politics work better to serve American interests, General Scowcroft is singularly deserving of this prize, awarded appropriately in memory of Hubert Humphrey. and $I$ and the other members of my committee. David Denoon and Jeanie Stanley, are proud to present it to him.

NOTE: General Scowcroft was unable to be present to accept his award (and he cannot accept the cash prize) but sent this message to the program chair:

"I regret that my responsibilities in Washington prevent me from joining you in Atlanta on the evening of August 31.

Hubert Humphrey was a man of intellect as well as of action, and, more important, a man of integrity, compassion, and courage. An award in his name sets a very high standard, and I am deeply honored to receive it.

Please accept my gratitude. Please also con. vey my congratulations to the other award recipients."

\section{Sincerely, \\ Brent Scowcroft}

Carey McWilliams Award $(\$ 500)$, presented each year to honor a major journalistic contribution to our understanding of politics.

Award Committee: Robert Wood, Wesleyan University, chair; C. Richard Hofstetter, San Diego State University; and Marvin Kalb. Harvard University.

\section{Recipient: Lesley Stahl, CBS News.}

Citation: The guiding principle for this award is not the distinction of the recipient in her or his chosen profession of journalism-if indeed journalism is really and truly a profession. Rather it is the contribution the journalist makes to another, perhaps even more dubious calling, political science, and more specifically, the study of politics.

That you stand in the foremost ranks of journalism today is clear. In the most competitive of national media where the networks and cable 


\section{Gazette}

news go head to head every day, you emerge after a decade of national reporting as a "tough lady" "who is in her second tour of duty as CBS White House correspondent, and you continue as moderator of Face the Nation. You are, according to TV Guide, "queen of the Sunday morning news shows." Sandra McElwaine credits you with "bringing new energy and prominence to the once-stodgy public broadcast." Colleagues and bosses call you tenacious, dogged, and ferocious in the pursuit of a story.

Those qualities are not the ones which prompt this award-for it is your contribution to the understanding of politics, your service to our craft, that we laud here now. In this context, it is your capacity day after day, year after year, and most especially in your interviews Sunday after Sunday by persistent, hard-nosed questions to extract admissions, identify motives, show political figures as they truly are, that provide us with a continuing stream of timely and realiable data. More especially, as author and spouse Aaron Latham observes, you "shape stories on issues rather than events."

Perhaps it was your growing up in Massachusetts which allowed you early on to observe political pathology at its darkest. Perhaps it was your education at Wheaton College as student and now trustee which gives you academic perspective, or perhaps it was your staff work with New York City's last successful Mayor, John Lindsay, that prepared you for Watergate and the White House thereafter.

Whatever the cause, you provide the absolutely essential facts on the key actors in American political life persuading them to say where they stand and what they think contrary to their own wary intentions and worst instincts. For continuing to ignore the routine press releases, avoid puff, resist oversimplification, and provide us with the hard facts on which our work depends, the American Political Science Association is pleased to award you with the Carey McWilliams Award for 1989. 